\title{
KAJIAN MINAT WIRAUSAHA MASYARAKAT ASLI TERNATE
}

\author{
Marwan, Abdul Rahman Jannang, Jannati \\ Universitas Khairun, STIEM Bongaya Makassar \\ A R T I C LE INFO
}

Keywords: Interests, Entrepreneurs,
Indigenous People.

Kata Kunci: Minat, Wirausaha, Masyarakat Asli.

Corresponding author:

\section{Marwan}

marwan.jamaluddin@yahoo.co.id
Abstract: This study aims to determine and analyze the antecedent variables that affect the entrepreneurial interest of the indigenous people of Ternate City and their impact on the realization of the entrepreneurial interest. The method used is quantitative research with the aim of revealing the various phenomena that surround it and at the same time revealing the problems it faces. For this reason, a representative sample who understands the factual conditions will be selected to be used as respondents to explore valid data for analysis. The results of the study show that 1) social norms have an effect on entrepreneurial interest and the direction is positive, meaning that the influence of social norms on entrepreneurial interest is unidirectional, which means that if social norms are good, entrepreneurial interest will be high. And vice versa. 2) ask entrepreneurship to have an influence on the implementation of entrepreneurial interest and the direction is positive indicating that the influence of entrepreneurial interest on the implementation of entrepreneurial interest is unidirectional, meaning that if entrepreneurial interest is high it will cause high entrepreneurial interest implementation and vice versa. While the locus of control variable has no effect on entrepreneurial interest and locus of control and social norms have no effect on the implementation of entrepreneurial interest in the indigenous people of Ternate City.

Abstrak: Penelitian ini bertujuan untuk mengetahui dan menganalisis variable-variabel anteseden yang mempengaruhi minat wirausaha masyarakat asli Kota Ternate dan dampaknya terhadap realisasi minat wirausaha tersebut. Metode yang digunakan adalah penelitian kuantitatif dengan tujuan untuk mengungkapkan berbagai fenomena yang melingkupinya dan sekaligus mengungkapkan permasalahan yang dihadapi nya. Untuk iti akan dipilih sampel yang representative yang memahami kondisi factual untuk dijadikan sebagai responden untuk menggali data yang valid untuk dianalisa. Hasil penelitian menunjukkkan bahwa 1) norma sosial berpengaruh terhadap minat wirausaha dan arahnya adalah positif artinya bahwa pengaruh norma sosial terhadap minat wirausaha adalah searah yang artinya adalah bahwa jika norma sosial itu baik maka minat wirausaha akan tinggi. Demikian juga sebaliknya. 2) minta wirausaha memiliki pengaruh terhadap implementasi minat wira usaha dan arahnya adalah positif menunjukkan bahwa pengaruh minat wirausaha terhadap implementasi minat wirausa adalah searah, artinya jika minat wira usaha tinggi maka akan menyebabkan implementasi minat wirausaha akan tinggi dan demikian juga sebaliknya. Sementara variabel locus of control tidak berpengaruh terhadap minat wirausaha dan locus of control serta norma sosial tidak berpengaruh terhadap implementasi minat wirausaha terhadap masyarakat asli Kota Ternate. 


\section{PENDAHULUAN}

\section{Latar Belakang}

Kewirausahaan yang baik bagi warga Negara merupakan bagian penting dalam pembangunan ekonomi. Oleh karena, dengan tingginya minat berwirausaha bagi warga sebuah Negara akan dapat mendorong aktifitas ekonomi sehingga dapat meningkatkan produksi barang maupun jasa. Hal ini pada gilirannya akan meningkatkan produktivitas secara aggregate dan juga daya saing. Meningkatnya produktifitas melalui kemampuan inovasi yang dapat merubah, menghasilkan sesuatu yang baru, relasi baru, akumulasi modal, baik berupa perbaikan usaha yang sudah ada (upgrading) maupun menghasilkan usaha baru.

Seorang wirausahawan adalah mereka yang berusaha dalam industri kreatif, dengan memanfaatkan jiwa kewirausahaannya, pengalaman, dan pengetahuan mereka. Industri kreatif merupakan industri yang berasal dari pemanfaatan kreativitas, keterampilan serta bakat individu untuk menciptakan kesejahteraan serta lapangan pekerjaan melalui penciptaan dan pemanfaatan daya kreasi dan daya cipta individu tersebut. Indonesia menempati urutan keempat, setelah AS, India, dan Inggris- berdasarkan permintaan advertising melalui mobile advertising (Kompas. 1 Januari dan 23 November 2003). Industri kreatif telah diklaim menjadi pendorong dalam ekonomi berbasis pengetahuan dan fasilitator bagi industri lain dan industri jasa (Hesmondhalgh, 2009).

Berdasarkan pada Republika on line tertanggal 18 Oktober 2018 bahwa "Satu fakta menarik tentang kewirausahaan, pada tahun 2018, di negara maju rata-rata 14 persen dari total penduduk usia kerja adalah enterpreneur, sementara di Indonesia hanya mencapai 3,1 persen," ujarnya dalam sambutannya saat mendapat penganugerahan gelar kehormatan Doctor Honoris Causa dari Universitas Pendidikan Iindonesia di Bandung. Kendati pada sumber lain mengungkapkan bahwa Puspayoga di Jakarta, Selasa (5/6), mengatakan, rasio wirausaha di Indonesia terbaru sudah meningkat menjadi 7\% lebih dari total penduduk Indonesia. Berita satu.com tertanggal 5 Juni 2018.

Sampai tahun 2015 jumlah enterpreneur di Indonesia ternyata belum cukup menggembirakan. Lebih jauh tentang data para enterpreneurship di Indosensia dikemukakan oleh "Secara persentase, jumlah wirausaha di negara kita hanya sekitar 3\%. Kalah dari negara tetangga di ASEAN seperti Malaysia, Singapura, dan Thailand yang sudah di atas 4\%," ujar Bamsoet.

Kota Ternate yang sedang tumbuh sedang berupaya membangun berbagai infrastruktur untuk dapat mendorong pertumbuhan ekonomi khusunya pada sector jasa, sebagai salah satu prioritas daerah. Adanya pembangunan infrastruktur pasar itu, diharapkan dapat mendorong wirausaha di sektor perdagangan di Ternate yang saat ini jumlahnya sekitar 2.600 orang, dalam beberapa tahun ke depan bisa meningkat sampai 5.000 orang, yang sebagian di antaranya diharapkan berada dalam kategori wirausaha skala menengah ke atas," katanya. Khususnya para masyarakat asli daerah.

Besarnya peluang wirausaha di Kota Ternate, banyak dimanfaatkan oleh para tenaga pendatang. Seperti untuk usaha-usaha pada sector perdagangan banyak dikelolah oleh para pendapatang dari Makassar, Sumatera, dan Gorontalo. Pada sector kuliner banyak digarap oleh para pendatang yang berasal dari Jawa, Makassar, dan Sumatera. Adapun untuk pengusaha local lebih banyak menggarap sector infrastruktur dan supplier yang memanfaatkan jaringan ke birokrasi. Terbatasnya para pelaku entrepreneurship di kalangan masyarakat asli local Ternate oleh karena rendahnya minat masyarakat local terhadap sector informal tersebut. Terdapat beberapa pendapat yang diungkapkan oleh para pemerhati dan akademisi tentang rendahnya minat tersebut, 
antara lain disebabkan oleh secara kultural masyarakat Kota Ternate adalah masyarakat kepualauan yang dahulunya terpola dengan kehidupan sebagai nelayan dan petani terutama pada sector tanaman perkebunan. Kondisi ini didukung oleh kondisi dan sumber daya alam yang tersedia yang sangat berlimpah di sekitar. Tradisi ini kemudian diturunkan dari satu generasi kepada generasi selanjutnya, bahkan hingga kini.

Factor kedua belum adanya usahanya nyata yang dilakukan oleh pemerintah daerah di dalam memberikan penguatan kepada masyarakat local untuk dapat memanfaatkan peluang usaha di daerah untuk peningkatan kesejahteraan mereka. Sehingga yang terjadi adalah adanya kompetsisi secara langsung dan bebas antara masyarakat local dengan para pendatang yang sesungguhnya telah memiliki kemampuan di dalam melihat dan memanfaatkan peluang. Hal ini menyebabkan adanya proses penyingkiran secara perlahan terhadap masyarakat sekitar.

Ketiga, adalah masih minimnya dukungan dari institusi pendidikan untuk memperkenalkan dan menumbuhkan minat kepada generasi saat ini untuk dapat tergerak lebih aktif dalam memanfaatkan berbagai peluang usaha yang ada di sekitar kota pelabuhan ini. Padahal seperti diketahui bahwa saat ini dengan adanya keterbatasan lapangan kerja pada sector formal, maka institusi pendidikan diharapkan dapat mendorong para luarannya untuk dapat lebih berperan di dalam menciptakan lapangan kerja ketimbang mencari pekerjaan. Seperti yang saat ini tengah marak terjadi di berbagai kota besar di Indonesia.

Kendati banyak menawarkan peluang bagi para wirausaha perkembangan dunia usaha relative perkembangannya lambat. Bahkan ada yang perlu untuk menjadi perhatian dari sejak awal, bahwa kondisi yang sedang berlangsung saat ini berpeluang untuk memicu timbulnya kecemburuan social di masyarakat pada masa yang akan dating. Sebab peluang di sector ini lebih banyak dinikmati oleh para masyarakat pendatang. Oleh karena itu perlu dilakukan intervensi oleh pemerintah melalui kebijakan-kebijakan yang berpihak dan tidak membiarkan proses berlangsung secara alami, dan sangat sedikit mendapatkan penguatan dari factor kebijakan pemerintah. Untuk itu perlu diawali oleh sebauh kajian secara sistematik untuk dapat mengungkap tentang perkembangan, dinamika, dan problematika sector dunia usaha di lingkup kota ternate.

Adapun faktor-faktor yang menjadi minat wirausaha dapat dikelompokkan dalam 2 aspek yaitu (Erlita, 2014): a) Faktor Internal, dengan beberapa indikator sebagai berikut: 1. Demografi. Faktor demografi ini meliputi usia, pengalaman dan pendidikan. 2. Kepribadian, ini terbagi menjadi dua, yaitu: a. Tipe Kepribadian b. Sifat-Sifat / Karakteristik Wirausahawan 3. Motivasi, ini terbagi menjadi tiga yakni motif untuk berkreativitas, untuk bekerja dan untuk berpendapatan. b) Faktor Eksternal, meliputi: 1. Lingkungan keluarga, meliputi dua aspek yaitu, interaksi dalam keluarga dan kondisi sosial ekonomi. 2. Lingkungan Kerja. Situasi kerja dinilai sebagai sarana atau lingkungan tempat untuk memulai usaha. Seorang wirausaha dapat menciptakan pekerjaannya dalam situasi apapun melalui bakat dan ketrampilan yang dimiliki

Lambing dan Kuehl (2000) menyatakan bahwa tujuan yang ingin dicapai seorang wirausahawan dipengaruhi oleh kebutuhan akan berprestasinya yang mendorong individu untuk menghasilkan yang terbaik dan biasanya memiliki inisiatif serta keinginan yang kuat untuk mengungkapkan ide-ide dalam pikirannya, menyampaikan gagasan demi mencapai suatu kesuksesan. Sebuah niat diperlukan untuk langkah awal dalam memulai wirausaha. Niat adalah keinginan tertentu seseorang untuk melakukan sesuatu atau beberapa tindakan, itu merupakan hasil dari pikiran sadar yang mengarahkan tingkah laku seseorang (Parker, 2004 dalam Adnyana \& Purnami, 2016). Penelitian yang akan ini dilaksanakan bertujuan untuk dapat Menyusun pemetaan wirausahawan berdasarkan pada factor biografi di Kota Ternate dan Menyusun rekomendasi yang 
akan menjadi dasar bagi pemerintah daerah kota Ternate untuk melakukan pembinaan dan pengembangan usaha kecil dan menengah di Kota Ternate

\section{TINJAUAN PUSTAKA}

\section{Konsep Wira Usaha}

Hebert \& Link (1988: 21) mendefinisikan wirausaha adalah seseorang yang terlibat dalam pertukaran untuk keuntungan. Dia adalah seseorang yang melaksanakan keputusan bisnis dalam menghadapi ketidakpastian. (Dalam William \& Nadin 2012). Sementara itu Coulter (2001) mendefinisikan wirausaha adalah proses dimana seorang individu atau kelompok individu menggunakan upaya terorganisir dan sarana untuk mengejar peluang untuk menciptakan nilai dan tumbuh dengan memenuhi keinginan dan kebutuhan melalui inovasi dan keunikan, tidak peduli apa sumber daya yang saat ini dikendalikan.

Beberapa defenisi lain tentang usaha kecil antara lain disampaiakan oleh Zimmerer(2008) mendefinisikan wirausaha adalah seseorang yang menciptakan bisnis baru dengan mengambil resiko dan ketidakpastian dmi mencapai keuntungan dan pertumbuhan dengan cara mengidentifikasi peluang yang signifikan dan menggabungkan sumber-sumber daya yang diperlukan sehingga sumber-sumber daya itu bisa dikapitalisasikan. Kuratko \& Hodgetts(2007) mendefinisikan wirausaha adalah seseorang dalam proses inovasi dan pembuatan usaha baru yang menggunakan gabungan antara empat dimensi major yaitu individual, organisasional, lingkungan dan proses.

Dalam penelitian dengan penelitian ini penulis memilih untuk menyimpulkan dari pengertian teori menurut para ahli,bahwa seorang wirausaha adalah seseorang yang mau mengambil resiko, mempunyai keterampilan dan kreativitas untuk menuju suatu kesuksesan. Atas dasar pengertian tersebut, maka para wirausahan merupakan orang yang berani mengambil resiko atas tujuan yang mereka tetapkan dengan mengorbankan segala keterampilan dan sumber daya yang dimilikinya.

\section{Factor- Faktor Yang Mempengaruhi Wira Usaha}

Faktor pendorong dalam Entrepreneurial Motivation McClelland (1971) Mengemukakan faktor pendorong motavasi wirausaha yaitu: berpendapat bahwa ada tiga faktor pendorong motivasi yang mempengaruhi perilaku dan sikap pekerja: kebutuhan untuk berprestasi, kebutuhan afiliasi, dan kebutuhan kekuasaan. (Lawrence \& Jordan 2009). Menurut (Omar, 2011) ada 2 faktor yang yang mempengaruhi entrepreneurial motivation yaitu push dan pull factors. Banyak literatur berfokus pada dua kelompok, mereka disebut sebagai push dan pull faktor (de Freitas, 1991).

Menurut Segal et al. (2005) ada beberapa faktor yang mempengaruhi entrepreneurial motivation yaitu (dalam Morales-Gualdrón, Gutiérrez-Gracia \& Dobón, 2009): a) Personal; b) Opportunity; c) Scientific knowledge; d) Resource avaibility; e) Incubator organization; f) Social networks. Keberadaan pengusaha sukses baik dalam lingkungan keluarga maupun di wilayah tempat tinggal individu, dan sikap masyarakat terhadap penciptaan bisnis baru, adalah aspek yang mempengaruhi persepsi kelayakan dan keinginan untuk menciptakan sebuah perusahaan (Shapero 1984) . Namun, bukti tentang aspek tersebut langka dan kontradiktif. Autio dan Kauranen (1994) dalam penelitian mereka terhadap pengusaha akademik Finlandia menemukan bahwa motif tersebut tidak penting dalam keputusan untuk membuat perusahaan, sementara Ding dan Stuart (2006), dalam sebuah studi yang menyelidiki latar belakang sosial dari 917 peneliti AS, 
menemukan bahwa keberadaan model peran dalam jaringan sosial penemu positif dapat mempengaruhi kemungkinan untuk menciptakan sebuah perusahaan.

Lachman (1980, 110) Menjelaskan bahwa kombinasi antara motivasi berprestasi yang tinggi dengan motivasi afiliasi yang rendah dapat memfasilitasi perilaku wirausaha lebih dari kombinasi lainnya. Selain itu Baron and Markman, (2000);Zhao and Seibert, (2006) mengemukakan memiliki motivasi afiliasi rendah tidak berarti pengusaha kurang dalam keterampilan sosial. Keterampilan sosial yang tampaknya penting bagi keberhasilan wirausaha, karena keterampilan sosial umumnya diperlukan bagi pengusaha untuk meyakinkan orang lain untuk berinvestasi atau membeli produk atau jasa. (Dalam Decker \& Weer, 2012).

\section{Minat Wira Usaha dan Faktor Yang Mempengaruhinya}

Menurut Katz \& Gartner dalam Indarti \& Rostiani (2008) intensi kewirausahaan diartikan sebagai proses pencarian informasi yang dapat digunakan untuk mencapai tujuan pembentukan suatu usaha. Intensi telah menjadi prediktor terbaik bagi perilaku berwirausaha seseorang (Ajzen \& Fishbein dalam Kautonen \& Luoto, 2008). Pengaruh keluarga, pendidikan dan pengalaman kerja pertama adalah faktor penting dalam pengembangan minat berwirausaha (Krueger \& Brazeal, 1994; Segal, Borgia, \& Schoenfeld, 2002 dalam Farzier \& Niehm, 2008). Orang tua memberikan dampak kuat pada pemilihan minat berwirausaha, penelitian menunjukkan para wirausaha biasanya memiliki orang tua yang juga seorang wirausaha (Peterman \& Kennedy, 2003 dalam Farzier \& Niehm, 2008). Pendidikan dan pengalaman kerja dapat mempengaruhi pilihan karir dengan mengenalkan ide-ide baru, membangun keterampilan yang diperlukan dan menyediakan akses pada role model (Nabi, Holden \& Walmsley, 2006; Van Auken, Fry, \& Stephens, 2006 dalam Sondari, 2009.

Kram (1983) and Shapero dan Sokol (1982) sebagaimana dikutip dalam Sondari (2009) menemukan bahwa pendidikan dan pelatihan mempengaruhi persepsi orang terhadap minat kewirausahaan, dengan menyediakan kesempatan untuk mensimulasikan memulai usaha dan dengan mengamati seorang role model. Sagie and Elizur (1999) mengutip Hisrich yang menyatakan: "entrepreneurship courses taken, increases the interest in starting a new venture a strong education base is almost a prerequisite for entrepreneurial activity and company formation in an area".

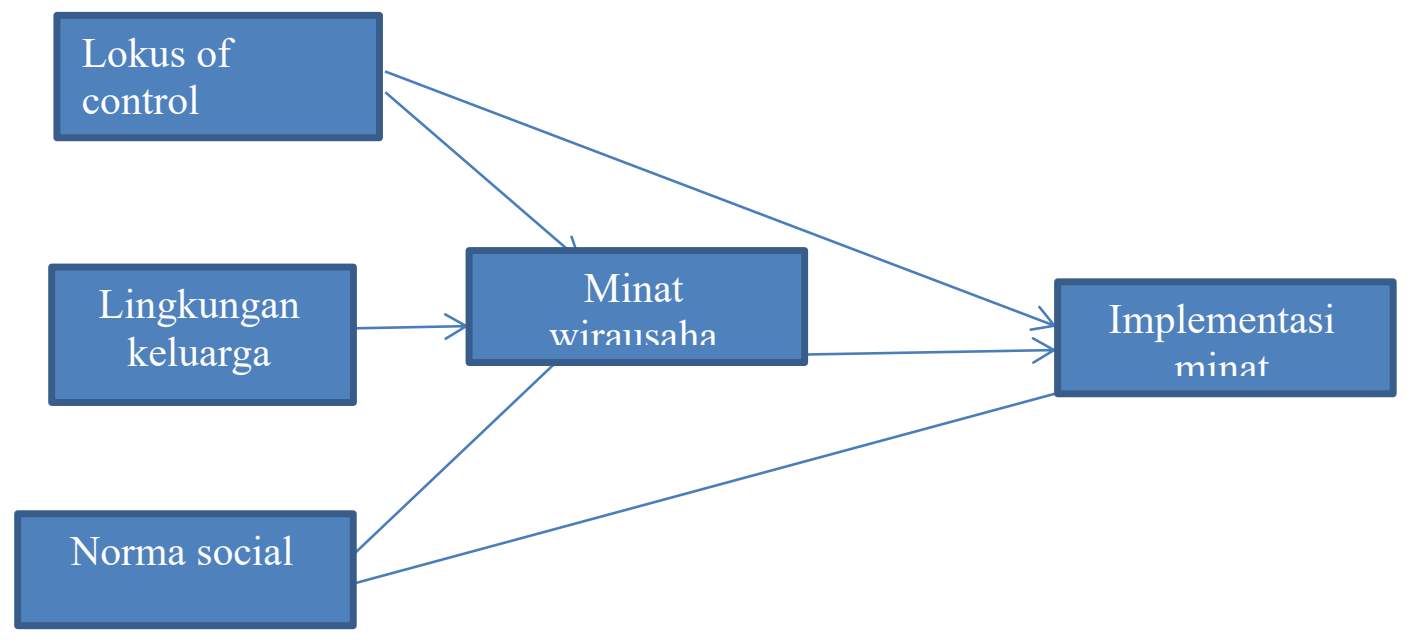


H1: Locus of Control berpengaruh terhadap minat wirausaha

$\mathrm{H}$ 2: Norma sosial berpengaruh terhadap minat wirausaha

H3: Locus of Control berpengaruh terhadap implementasi minat wirausaha

H4: Norma sosial berpengaruh terhadap implementasi minat wirausaha

H5: Minat wirausaha berpengaruh terhadap implementasi minat wirausaha

H6: Lingkungan keluarga sebagai variabel yang memperkuat pengaruh Locus of Control terhadap implementsi minat wirausaha

H7: Lingkungan keluarga sebagai variabel yang memperkuat pengaruh minat wirausaha terhadap implementasi minat wirausaha

H8: Lingkungan keluarga sebagai variabel yang memperkuat pengaruh norma sosial terhadap implementasi minat wirausaha

\section{METODE PENELITIAN}

\section{Jenis Penelitian}

Penelitian ini termasuk penelitian kualitatif dengan pendekatan konstruksionis sosial (Gergen, 2009), naratif (Polkinghorne, 1988) dan interpretatif (Smith et al. 2009). Pendekatan naratif menjadi diakui sebagai metode yang valid dalam studi interpretatif kewirausahaan.

\section{Subjek Penelitian}

Subyek penelitian adalah masyarakat asli di Kota Ternate, yaitu masyarakat yang secara secara turun temurun telah berdomisili di Kota Ternate dalam jangka yang panjang sehingga memiliki identitas sebagai masyarakat local. Olehnya itu jumlah masyarakat local ini dibandingklan dengan penduduk yang lainnya, adalah mayoritas. Sehingga jumlahnya sangat besar. Untuk itu, penelitian ini dilakukan pada sampel yang terpilih. Secara garis besar masyarakat yang berdomisili di Kota Ternate, dalam hal bidang kerja dapat dibagi pada beberapa bidang yaitu: pegawai baik pada sector public maupun privat, petani/nelayan, pengusaha, dan masyarakat yang masih mencari kerja/menganggur. Oleh sebab itu agar data yang dikumpulkan dapat mencerminkan keadaan yang sesungguhnya maka, sampel diambil berdasarkan pada kelompokkelompok tersebut. Jumlah sampel yang dianggap reprensentatif adalah sebanyak 100 orang, sehingga masing-masing kelompok tersebut akan diambil sebanyak 25 orang sampel.

\section{Teknik Pengumpulan Data}

Di dalam pengumpulan data tersebut ketiga metode tersebut digunakan dengan cara dan waktu yang berbeda.

\section{Kuisioner}

Pada tahap awal pengumpulan data dilakukan dengan menggunakan kuisoner. Yaitu sebuah instrument yang terdiri atas item-item pernyataan dari variable penelitian dengan sifatnya tertutup. Yakni pada setiap pernyataan telah disertai dengan 5 alternative-alternatif jawaban yang akan dipilih oleh para responden yang dianggap paling mendekati dengan isi dari setiap pernyataan. 


\section{Observasi}

Adalah tahap pengumpulan data dengan melakukan pengamatan yang terjadi pada lokasi penelitian untuk memberikan rasionalisasi terhadap temuan-temuan penelitian. Hal ini dilakukan agar temuan statistic dapat dijelaskan dengan fakta empiric.

Dept-interview

Dengan bantuan instrumen berupa pedoman wawancara, alat perekaman wawancara dan dokumen wawancara direkam dan diberi kode dengan seperangkat kategori yang dikembangkan melalui analisis wacana (discourse analysis) (Potter dan Wetherall, 1987). Ada dua tahap memberchek yang peneliti lakukan yakni: dilakukan segera setelah data masuk saat wawancara dan observasi, dan setelah data rekaman ditranskrip. Audit trail adalah upaya memeriksa kesesuaian antara temuan peneliti dengan data yang terhimpun melalui pelacakan terhadap catatan-catatan lapangan, metode pengumpulan dan teknik analisisnya. Dalam penelitian ini audit trail terbuka untuk siapapun. Pengamatan terus menerus peneliti lakukan agar dapat melihat fenomena pada latar penelitian secara cermat, terinci dan mendalam. Analisis wacana (discourse analysis) dan tematik digunakan untuk menafsirkan narasi kisah hidup tiga pengusaha di industri kreatif.

\section{HASIL PENELITIAN DAN PEMBAHASAN}

\section{Gambaran Umum Objek Penelitian}

Kota Ternate terdiri dari kesatuan kawasan yang terdiri dari 5 (lima) gugusan pulau dalam satu kluster pengembangan, yakni Pulau Ternate, Pulau Hiri, Pulau Tifure dan Pulau Mayau (Batang Dua). Ditinjau dari fungsional kawasan perkotaan, maka kota Ternate berfungsi sebagai pusat pemerintahan, pusat perekonomian dan pusat pariwisata. Saat ini dengan memanfaatkan potensinya mengembangkan diri menjadi pusat jasa dan industry. Pada masa yang akan datang potensi itu akan terus dikembangkan tidak hanya untuk melayani daerah sekitarnya tetapi akan mengarah kepada kawasan pasifik dan sekitarnya.

Salah satu potensi yang dimiliki Kota Ternate adalah potensi produk hasil industri yang meliputi: 1) Industri hasil pertanian dan kehutanan, 3) Industri Logam, mesin dan kimia, 4) Industri perikanan, 5) Industri pariwisata, 6) Industri perdagangan dan Jasa. Namun demikian kegiatan sektor industri di Kota Ternate masih terbatas pada industri kecil, dan hanya sebagian industri skala menengah.

Saat ini Kota Ternate berkembang pesat sebagai kota jasa, karena meskipun relative kecil jika dibandingkan dengan kota-kota liannya di Indonesia tetapi di provinsi Maluku Utara Kota Ternate merupakan centrum dari berbagai aktifitas masyarakat. Oleh karena di Kota Ternate selain jumlah penduduknya paling besar dibandingkan dengan daerah lainnya, di daerah ini terdapat fasilitas yang cukup baik. Hal ini pula yang mendorong Kota Ternate menjelma sebagai Kota industry khususnya industry jasa dan juga sebagai Kota Perdagangan.

Di Kota Ternate saat ini semakin tumbuhnya kegiatan usaha berskala menengah dan kecil. Berkembangnya sektor tersebut karena didukung oleh sejumlah fasilitas jasa perdagangan seperti Hotel, Pasar Umum, Perbankan, Pelabuhan, Terminal, dll. Tersedianya berbagai fasilitas jasa perdagangan dan perhubungan tersebut memungkinkan berkembangnya usaha industri walaupun dalam skala menengah dan kecil. 


\section{Uji Validitas Instrumen Penelitian}

Instrument yang digunakan dalam penelitian ini, terlebih dahulu dilakukan uji instrument untuk mengetahui bahwa instrument yang digunakan sudah valid atau sah dalam mengukur apa yang ingin diukur dengan menggunkan kriteria Total Pearson Correlation $>0,3$. Uji instrument dilakukan dengan cara, kuesioner dibagikan ke 30 responden. Dari data analisis diatas menunjukan bahwa instrument pertanyaan dari variabel Locus of control (X1), Norma Sosial (X2), Lingkungan Keluarga (Z), Niat Wirausaha (Y1) dan Implementasi Niat Wirausaha (Y2) adalah valid karena R hitung lebih besar dari nilai kritis. Dengan demikian dikatakan valid dan dapat digunakan untuk penelitian.

\section{Uji Reabilitas}

Jika nilai Cronbach Alpha $>0,60$ maka bahwa suatu konstruk atau variabel dapat dikatakan realibel. Adapun hasil uji realibilitas menggunakan SPSS v. 20 adalah sebagai berikut:

\section{Tabel 4.1. Hasil Uji Realibilitas}

\begin{tabular}{|c|l|c|c|c|}
\hline No & \multicolumn{1}{|c|}{ Variabel } & $\begin{array}{c}\text { Cronbach } \\
\text { Alpha }\end{array}$ & $\begin{array}{c}\text { Cronbach Alpha yang } \\
\text { diisyaratkan }\end{array}$ & Kesimpulan \\
\hline 1 & Locus of control (X1) & 0,860 & 0,60 & Realibel \\
\hline 2 & Norma Sosial (X2) & 0,836 & 0,60 & Realibel \\
\hline 3 & Lingkungan Keluarga (Z) & 0,747 & 0,60 & Realibel \\
\hline 4 & Minat Wirausaha (Y1) & 0,890 & 0,60 & Realibel \\
\hline 5 & Implementasi Minat Wirausaha (Y2) & 0,882 & 0,60 & . \\
\hline
\end{tabular}

Sumber: Data primer diolah, 2019

Dari data analisis dengan nilai Cronbach Alpha tersebut menunjukan bahwa nilai cukup tinggi di atas standar. Dengan demikian dikatakan realibel dan dapat digunakan untuk penelitian.

\section{Uji Asumsi Klasik Statistik}

Uji asumsi klasik statistik dalam penelitian ini dilakukan untukmemastikan bahwa data yang digunakan bebas dari asumsi klasik dan datanya layak untuk dilakukan analisis selanjutnya. Uji asumsi klasik statistik meliputi:

\section{Uji Normalitas}

Uji normalitas menggunakan tes Kolmogorov-Smirnov $Z$ dan data dikatakan normal bila hasil uji normalitas menunjukkan bahwa nilai Asymp. Sig. (2-tailed) lebih besar dari 0,05. Berdasarkan hasil uji normalitas menunjukkan bahwa semua data pada variabel X1, X2, Z, Y1 maupun Y2 nilai Asymp. Sig. (2-tailed) > 0,05 maka dapat dikatakan data yang digunakan normal.

\section{Uji Multikolinearitas}

Uji multikolinearitas dilakukan 2 (dua) kali berdasarkan pada model dalam penelitian ini. Syarat bebas dari multikolinearitas bila nilai VIF lebih kecil dari nilai 10 pada Collinearity Statistics. Hasil uji multikolinearitas pada tahapan pertama hasil uji multikolinearitas menunjukkan nilai VIF X1 maupun X2 semuanya lebih kecil dari 10, maka data yang digunakan dalam penelitian ini bebas dari multikolinearitas. Selanjutnya dilakukan pengujian multikolinearitas pada tahapan kedua dan hasilnya di tampilkan kedua tersebut menunjukkan nilai VIF X1, X2, Z maupun Y1 semua nilainya lebih kecil dari 10, maka data yang digunakan dalam penelitian ini bebas dari multikolinearitas.

\section{Uji Heterokedastisitas}


Data dikatakan bebas dari heterokedastisitas bila scatterplot tidak membentuk pola dan penyebaraannya menyebar. Hasil uji heterokedastisitas ditampilkan pada hasil uji heterokedastisitas tersebut menunjukkan bahwa titik-titik scatterplot menyebar dan tidak membentuk suatu pola atau model, dengan demikian dapat dikatakan bahwa data yang dipergunakan dalam penelitian ini bebas dari heterokedastisitas.

\section{Uji Autokorelasi}

Uji asumsi klasik statistik yang terakhir adalah uji autokorelasi dengan menggunakan uji DurbinWatson. Hasil uji autokorelasi menunjukkan bahwa nilai Durbin-Watson sebesar 1,674. Artinya nilai tersebut $1,65<1,674<2,35$ maka dikatakan data yang dipergunakan tidak terjadi autokorelasi.

\section{Menguji Hipotesis}

Variabel penelitian ini dibuat berdasarkan teori dan studi empiris terdahulu seperti gambar di bawah ini:

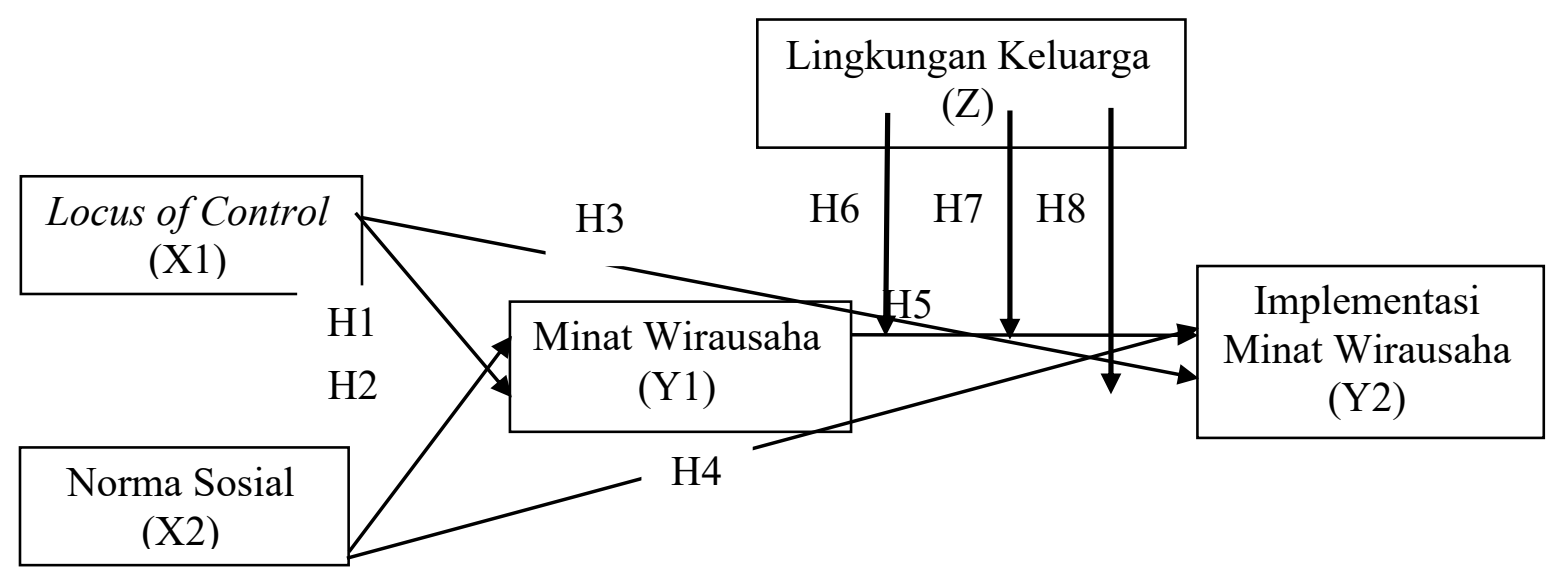

Gambar 4.1. Kerangka Konsep Penelitian berikut:

Berdasarkan pada Gambar 4.1 tersebut, maka dapat dibuat hipotesis penelitian sebagai

H1: Locus of Control berpengaruh terhadap minat wirausaha

$\mathrm{H} 2$ : Norma sosial berpengaruh terhadap minat wirausaha

H3: Locus of Control berpengaruh terhadap implementasi minat wirausaha

H4: Norma sosial berpengaruh terhadap implementasi minat wirausaha

H5: Minat wirausaha berpengaruh terhadap implementasi minat wirausaha

H6: Lingkungan keluarga sebagai variabel yang memperkuat pengaruh Locus of Control terhadap implementsi minat wirausaha

H7: Lingkungan keluarga sebagai variabel yang memperkuat pengaruh minat wirausaha terhadap implementasi minat wirausaha

H8: Lingkungan keluarga sebagai variabel yang memperkuat pengaruh norma sosial terhadap implementasi minat wirausaha 
Menganalisis hipotesis penelitian tersebut maka digunakan analisis jalur (Part Analysis) dengan bantuan software SPSS versi 20. Dengan demikian maka analisis regresinya bertingkat atau bertahap. Model untuk analisis regresi tahap I (pertama) sebagai berikut:

$\mathrm{H} 1$

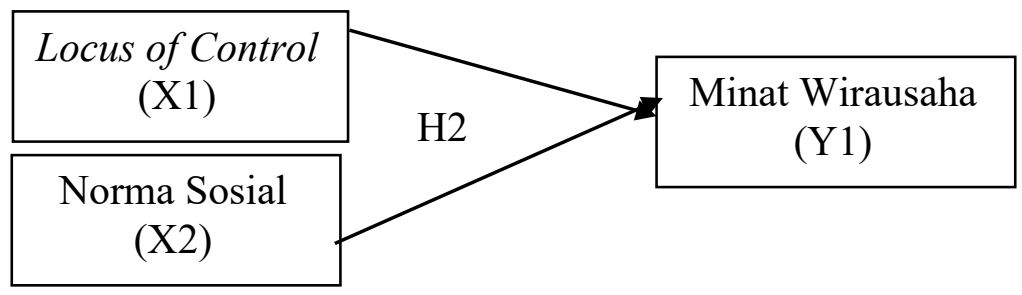

\section{Gambar 4.2. Model Analisis Tahap I}

Berdasarkan pada Gambar 4.2 Model Analsis Tahap I, maka persamaan regresinya dapat dibuat sebagai berikut:

$\mathrm{Y} 1=\mathrm{a}+\mathrm{b} 1 . \mathrm{X} 1+\mathrm{b} 2 . \mathrm{X} 2+\mathrm{e}$

Untuk mengetahui keseuaian model yang terbentuk pada tahap I tersebut maka dapat dilihat pada nilai Adjusted $R$ Square sebagaimana yang di tampilkan dalam Tabel 4.12

\section{Tabel 4.2. Keseuaian Model Tahap I Model Summary ${ }^{b}$}

\begin{tabular}{|l|l|r|r|r|}
\hline Model & R & R Square & Adjusted R Square & Std. Error of the Estimate \\
\hline 1 & $.643^{\mathrm{a}}$ & .413 & .401 & 4.17285 \\
\hline
\end{tabular}

a. Predictors: (Constant), X2, X1

b. Dependent Variable: Y1

Kesesuaian model yang terbentuk pada tahap I dapat dilihat pada nilai Adjusted $R$ Square sebesar 0,401 atai $40,1 \%$. Nilai tersebut mengandung makna bahwa variabel anteseden atau variabel yang mempengaruhi minat wirausaha hanya membentuk sebesar $40,1 \%$ sedangkan sisanya yang sebesar 59,9\% dapat dibentuk oleh variabel lain. Sedangkan untuk nilai R sebesar 0,643 yang mengandung arti bahwa korelasi antara variabel (X1) dan variabel (X2) terhadap variabel (Y1) sudah baik atau korelasi kuat dengan korelasi sebesar 64,3\%

berikut ini:

Hasil analisis regresi berganda pada Model Analsis Tahap I di tampilkan pada Tabel 4.3.

Tabel 4.3. Hasil regresi Tahap I

Coefficients $^{\mathrm{a}}$

\begin{tabular}{|c|c|c|c|c|c|c|}
\hline \multirow{2}{*}{\multicolumn{2}{|c|}{ Model }} & \multicolumn{2}{|c|}{$\begin{array}{l}\text { Unstandardized } \\
\text { Coefficients }\end{array}$} & \multirow{2}{*}{$\begin{array}{c}\text { Standardized } \\
\text { Coefficients }\end{array}$} & \multirow[t]{2}{*}{$\mathrm{T}$} & \multirow[t]{2}{*}{ Sig. } \\
\hline & & B & Std. Error & & & \\
\hline \multirow{3}{*}{1} & (Constant) & 9.735 & 4.242 & & 2.295 & .024 \\
\hline & $\mathrm{X} 1$ & -.106 & .123 & -.071 & -.862 & .391 \\
\hline & $\mathrm{X} 2$ & .868 & .108 & .662 & 8.056 & .000 \\
\hline
\end{tabular}


a. Dependent Variable: Y1

Sumber: Data Primer diolah SPSS versi 20, Tahun 2019

Berdasarkan hasil analisis regresi berganda dalam Tabel 4.3., menunjukkan untuk nilai constant: $\mathrm{t}$ hitung $(2,295)>\mathrm{t}_{\text {tabel }}(1,66)$ dan nilai sig. $(0,024)<\alpha(0,05)$ yang berarti nilai constant signifikan. Selanjutnya nilai $\mathrm{X} 1$ yaitu $\mathrm{t}_{\text {hitung }}(0,862)<\mathrm{t}$ tabel $(1,66)$ dan nilai sig. $(0,391)>\alpha(0,05)$, artinya hipotesis pertama (H1): Locus of Control berpengaruh terhadap minat wirausaha tidak terbukti atau $\mathrm{H} 1$ ditolak. Sedangkan untuk nilai $\mathrm{X} 2$ yaitu $\mathrm{t}$ hitung $(8,056)>\mathrm{t}$ tabel $(1,66)$ dan nilai sig. $(0,000)<\alpha(0,05)$, artinya hipotesis kedua $(\mathrm{H} 2)$ : Norma sosial berpengaruh terhadap minat wirausaha terbukti atau $\mathrm{H} 2$ diterima. Maka model persamaan regresi tahap I yaitu:

$\mathrm{Y}=9.735-0,106 \mathrm{X} 1+0,868 \mathrm{X} 2+4.242 \mathrm{e}$

Selanjutnya dibuat model analisis tahap II, dan model tersebut belum dimasukkan variabel moderasinya. Modelnya sebagai berikut:

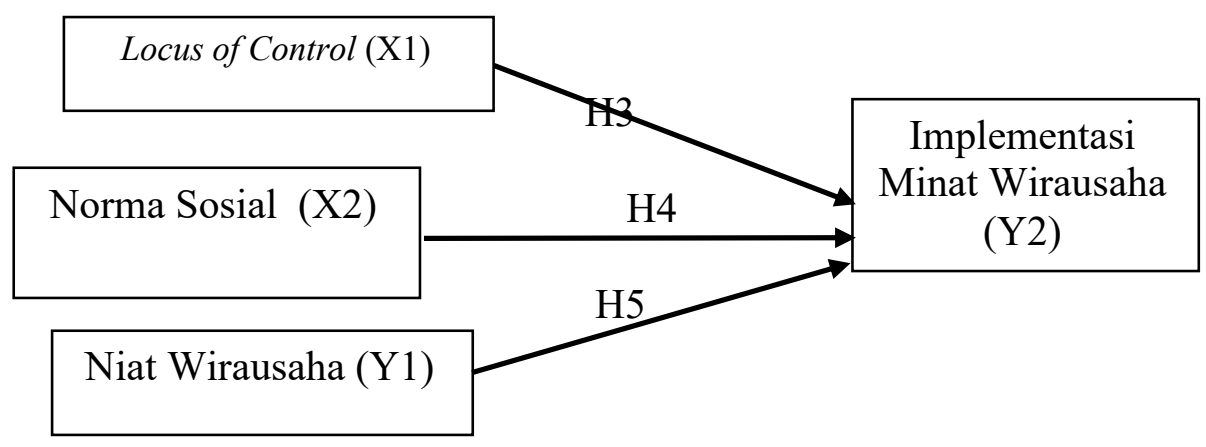

Gambar 4.3. Model Analisis Tahap II

Berdasarkan pada Gambar 4.3 Model Analsis Tahap II, maka persamaan regresinya dapat dibuat sebagai berikut:

$$
\mathrm{Y} 2=\mathrm{a}+\mathrm{b} 1 . \mathrm{X} 1+\mathrm{b} 2 . \mathrm{X} 2+\mathrm{b} 3 . \mathrm{Y} 1+\mathrm{e}
$$

Untuk mengetahui kesesuaian model yang terbentuk pada tahap II tersebut maka dapat dilihat pada nilai Adjusted $R$ Square sebagaimana yang di tampilkan dalam Tabel 4.4.

\section{Tabel 4.4. Keseuaian Model Tahap II Model Summary ${ }^{b}$}

\begin{tabular}{|l|r|r|r|r|}
\hline Model & R & R Square & Adjusted R Square & Std. Error of the Estimate \\
\hline 1 & $.785^{\mathrm{a}}$ & .616 & .604 & 3.52098 \\
\hline
\end{tabular}

a. Predictors: (Constant), Y1, X1, X2

b. Dependent Variable: Y2 
Kesesuaian model yang terbentuk pada tahap II tersebut dapat dilihat pada nilai Adjusted $R$ Square sebesar 0,604 atai 60,4\%. Nilai tersebut mengandung makna bahwa variabel anteseden atau variabel yang mempengaruhi implementasi minat wirausaha dibentuk sebesar 60,4\% sedangkan sisanya yang sebesar 39,9\% dapat dibentuk oleh variabel lain. Sedangkan untuk nilai $\mathrm{R}$ sebesar 0,785 yang mengandung arti bahwa korelasi antara variabel (X1) dan variabel (X2) maupun variabel (Y1) terhadap variabel (Y2) sudah sangat baik atau korelasi sangat kuat dengan nilai korelasi sebesar $78,5 \%$

Hasil analisis regresi berganda pada Model Analsis Tahap II belum dimasukkan variabel moderasinya di tampilkan pada Tabel 4.5. berikut ini:

Tabel 4.5. Hasil regresi Tahap II

Coefficients $^{\mathrm{a}}$

\begin{tabular}{|c|c|c|c|c|c|c|}
\hline \multirow{2}{*}{\multicolumn{2}{|c|}{ Model }} & \multicolumn{2}{|c|}{ Unstandardized Coefficients } & \multirow{2}{*}{$\begin{array}{c}\begin{array}{c}\text { Standardized } \\
\text { Coefficients }\end{array} \\
\text { Beta }\end{array}$} & \multirow[t]{2}{*}{$\mathrm{T}$} & \multirow[t]{2}{*}{ Sig. } \\
\hline & & B & Std. Error & & & \\
\hline \multirow{4}{*}{1} & (Constant) & -5.152 & 3.675 & & -1.402 & .164 \\
\hline & $\mathrm{X} 1$ & .181 & .104 & .117 & 1.742 & .085 \\
\hline & $\mathrm{X} 2$ & .192 & .117 & .141 & 1.633 & .106 \\
\hline & Y1 & .682 & .086 & .657 & 7.959 & .000 \\
\hline
\end{tabular}

a. Dependent Variable: Y2

Sumber: Data Primer diolah SPSS versi 20, Tahun 2019

Berdasarkan hasil analisis regresi berganda dalam Tabel 4.5. menunjukkan untuk nilai constant: $t_{\text {hitung }}(1,402)<t_{\text {tabel }}(1,66)$ dan nilai sig. $(0,164)>\alpha(0,05)$ yang berarti nilai constant tidak signifikan. Selanjutnya nilai X1 yaitu $t_{\text {hitung }}(1,742)>t$ tabel $(1,66)$ dan nilai sig. $(0,085)>\alpha$ $(0,05)$, artinya hipotesis ketiga $(\mathrm{H} 3)$ : Locus of Control berpengaruh terhadap implementsi minat wirausaha tidak terbukti atau $\mathrm{H} 3$ ditolok. Sedangkan untuk nilai X2 yaitu $t$ hitung $(1,633)<\mathrm{t}$ tabel $(1,66)$ dan nilai sig. $(0,106)>\alpha(0,05)$, artinya hipotesis keempat $(\mathrm{H} 4)$ : Norma sosial berpengaruh terhadap implementasi minat wirausaha tidak terbukti atau H4 ditolak. Selanjutnya untuk nilai Y1 yaitu $t_{\text {hitung }}(7,959)>t_{\text {tabel }}(1,66)$ dan nilai sig. $(0,000)<\alpha(0,05)$, artinya hipotesis kelima (H5): Minat wirausaha berpengaruh terhadap implementasi minat wirausaha terbukti atau H5 diterima. Maka model persamaan regresi tahap II yaitu:

$$
\mathrm{Y}=-5.152+181 \mathrm{X} 1+192 \mathrm{X} 2+682 \mathrm{Y} 1+3.675 \mathrm{e}
$$

Langkah berikutnya dibuat model analisis tahap III, dan model tersebut sudah dimasukkan variabel Lingkungan Keluarga (Z) sebagai variabel moderasi. Model tahap ke III sebagai berikut: 


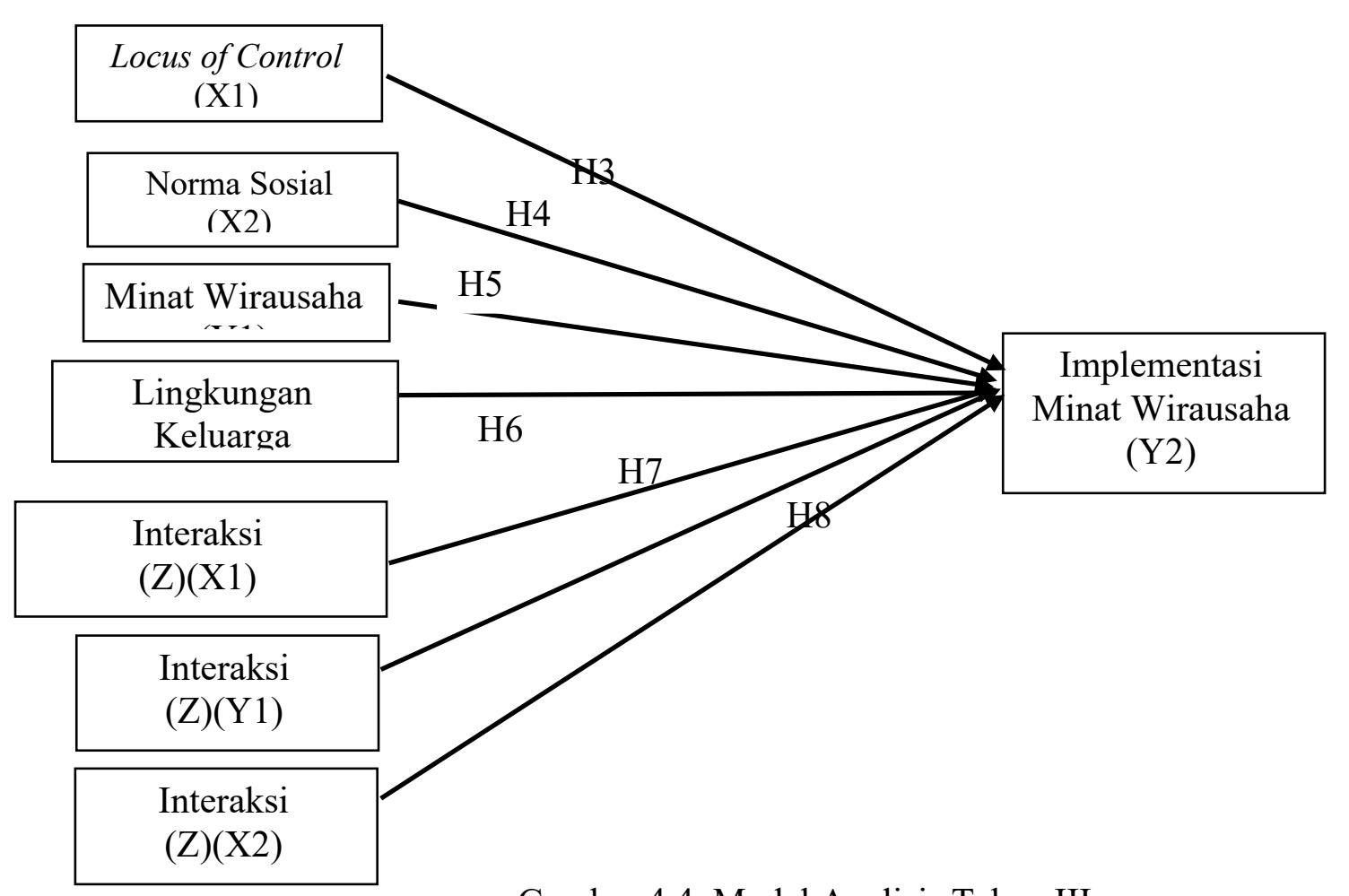

Gambar 4.4. Model Analisis Tahap III

Berdasarkan pada Gambar 4.4 Model Analsis Tahap III, maka persamaan regresinya dapat dibuat sebagai berikut:

$\mathrm{Y} 2=\mathrm{a}+\mathrm{b} 1 . \mathrm{X} 1+\mathrm{b} 2 . \mathrm{X} 2+\mathrm{b} 3 . \mathrm{Y} 1+\mathrm{b} 4 . \mathrm{Z}+\mathrm{b} 5 .(\mathrm{Z})(\mathrm{X} 1)+\mathrm{b} 6 .(\mathrm{Z})(\mathrm{Y} 1)+\mathrm{b} 7 .(\mathrm{Z})(\mathrm{X} 2)+\mathrm{e}$

Selanjutnya untuk mengetahui kesesuaian model yang terbentuk pada tahap III tersebut maka dapat dilihat pada nilai Adjusted $R$ Square sebagaimana yang di tampilkan dalam Tabel 4.6.

Tabel 4.6. Keseuaian Model Tahap III Model Summary

\begin{tabular}{|l|l|r|r|r|}
\hline Model & R & R Square & Adjusted R Square & Std. Error of the Estimate \\
\hline 1 & $.798^{\mathrm{a}}$ & .637 & .610 & 3.49658 \\
\hline
\end{tabular}

a. Predictors: (Constant), Y1.Z, X1, X2, Y1, Z, X2.Z, X1.Z

b. Dependent Variable: Y2

Kesesuaian model yang terbentuk pada tahap III tersebut setelah variabel lingkungan keluarga diposisikan sebagai variabel moderasi, maka dapat dilihat pada nilai Adjusted $R$ Square sebesar 0,610 atai 61\%. Nilai tersebut mengandung makna bahwa variabel anteseden atau variabel yang mempengaruhi implementasi minat wirausaha dibentuk sebesar $61 \%$ sedangkan sisanya yang sebesar 39\% dapat dibentuk oleh variabel lain. Sedangkan untuk nilai R sebesar 0,798 yang mengandung arti bahwa korelasi antara variabel (X1), variabel (X2), variabel (Y1), variabel moderasi (Z), variabel interaksi pertama (X1.Z) maupun variabel interaksi kedua (X2.Z) terhadap variabel (Y2) sudah sangat baik atau korelasi sangat kuat dengan nilai korelasi sebesar 
79,8\%Kemudian hasil analisis regresi berganda pada Model Analsis Tahap III telah dimasukkan variabel moderasinya di tampilkan pada Tabel 4.7. berikut ini:

Tabel 4.7. Hasil Regresi Tahap III

Coefficients $^{\mathrm{a}}$

\begin{tabular}{|c|c|c|c|c|c|c|}
\hline \multicolumn{2}{|c|}{ Model } & \multicolumn{2}{|c|}{ Unstandardized Coefficients } & \multirow{2}{*}{$\begin{array}{c}\text { Standardized } \\
\text { Coefficients } \\
\text { Beta }\end{array}$} & \multirow[t]{2}{*}{$\mathrm{T}$} & \multirow[t]{2}{*}{ Sig. } \\
\hline & & B & Std. Error & & & \\
\hline \multirow{8}{*}{1} & (Constant) & -6.030 & 17.236 & & -.350 & .727 \\
\hline & $\mathrm{X} 1$ & .660 & .579 & .425 & 1.139 & .257 \\
\hline & $\mathrm{X} 2$ & .198 & .609 & .146 & .326 & .745 \\
\hline & Y1 & .064 & .382 & .062 & .168 & .867 \\
\hline & Z & .097 & .780 & .091 & .125 & .901 \\
\hline & $\mathrm{X} 1 . \mathrm{Z}$ & -.023 & .026 & -.944 & -.895 & .373 \\
\hline & $\mathrm{X} 2 . \mathrm{Z}$ & -.002 & .026 & -.093 & -.093 & .926 \\
\hline & Y1.Z & .029 & .017 & 1.219 & 1.661 & .100 \\
\hline
\end{tabular}

a. Dependent Variable: Y2

Sumber: Data Primer diolah SPSS versi 20, Tahun 2019

Berdasarkan hasil analisis regresi berganda dalam Tabel 4.7. menunjukkan bahwa semua variabel X1, X2, Y1, Z, X1.Z, X2.Z dan Y1.Z memiliki nilai $t_{\text {hitung }}<(1,66)$ dan nilai sig. $(0,085)$ $>\alpha(0,05)$. Artinya, variabel lingkungan keluarga bukan sebagai variabel moderasi yang memperkuat pengaruh hubungan X1, X2 dan Y1 terhadap variabel Y2. Namun sebagai variabel yang memperlemah hubungan variabel X1, X2, Y1 terhadap variabel implementasi minat wirausaha (Y2).

\section{Pembahasan Hasil Penelitian}

\section{Locus of Control berpengaruh terhadap Minat Wirausaha}

Hipotesis pertama menyatakan bahwa Locus of Control berpengaruh terhadap Minat Wirausaha tidak terbukti atau ditolak. Artinya walaupun locus of control (X1) semakin meningkat maka tidak dapat memberikan pengaruh pada minat wirausaha (Y1). Walaupun hasil persepsi responden menunjukkan bahwa Locus of Control sudah berjalan dengan sangat baik namun tidak dapat mempengaruhi minat wirausaha masyarakat di Kota Ternate.

Dengan demikian temuan bahwa lokus of control of control tidak memiliki pengaruh terhadap Minat wirausaha masyarakat local Ternate secara empiric dapt terlihat dari fakta empiric tersebut di atas. Temuan penelitian ini sejalan dengan beberapa penelitian terdahulu, diantaranya adalah yang dilakukan oleh Nurul Indarti dan Stein Kristiansen (2003:89) melaklukan penelitian terhadap siswa di Norwegia, mengungkapkan bahwa locus of control tidak memiliki pengaruh yang signifikan terhadap niat wirausaha. Hal yang sama juga ditemukan oleh Oni Bamikole dan Foluso Ilesanmi $(2012 ; 81)$ yang penelitiannya mencoba untuk mengungkap korelasi antara lokus of control dan kemampuan entrepreneurship mengemukakan bahwa tidak terdapat hubungan yang signifikan.

Namun demikian, temuan penelitian berbeda dengan beberapa penelitian lainnya diantaranya yang dilakukan oleh Hermawan, Soetjipto, Rahayu (2016:147) mengungkapkan bahwa lokus of control memiliki pengaruh yang signifikan terhadap minat entrepreneurship. Penelitian tersebut dilakukan pada siswa SMK di Kota Malang. Demikian juga dengan penelitian yang dilakukan oleh Rahayu, 2010; Oktabriyantina et al, 2014 menemukan bahwa locus of control tidak berpengaruh terhadap need for achievement siswa, need for achievement tumbuh karena 
adanya rangsangan dari lingkungan sekitar yang membuat individu untuk lebih bereksistensi diantara yang lainnya. Selain hal tersebut juga tidak sejalan dengan hasil penelitian dari (I Gusti, 2016; Dinis et al., 2013; Hisrich, R.D, 2008; Uddin dan Bose, 2012; Ayodele, 2013) menemukan bahwa locus of control berpengaruh positif dan signifikan terhadap niat berwirausaha. locus of control yang semakin baik dapat meningkatkan niat nerwirausaha.

Locus of control menurut Kreitner dan Kinicki dalam (Wiriani et al., 2013), terdiri dari dua konstruk yaitu internal dan eksternal, dimana internal locus of control apabila seseorang meyakini bahwa apa yang terjadi selalu berada dalam kontrolnya dan dia selalu mengambil peran serta bertanggung jawab dalam setiap pengambilan keputusan, sedangkan external locus of control apabila seseorang meyakini bahwa kejadian dalam hidupnya berada diluar kontrolnya.

\section{Norma sosial berpengaruh terhadap Minat Wirausaha}

Hipotesis kedua menyatakan bahwa norma sosial berpengaruh terhadap minat wirausaha terbukti atau diterima. Artinya norma sosial yang semakin kondusif ditengah-tengah masyarakat Kota Ternate maka dapat meningkatkan minat wirausaha masyarakat. Hal tersebut didukung kondisi aktual tentang norma sosial yang dipersepsikan responden sudah berjalan dengan baik. Temuan ini mengindikasikan bahwa norma social mempengaruhi minat wirausaha, dan arah hubungannya adalah positif. Artinya bahwa semakin tinggi atau semakin baik norma social di masyarakat local ternate maka akan menyebabkan tinggi niat berwirausaha. Besarnya nilai pengaruh tersebut adalah sebesar 0,868 sehingga variable ini berpengaruh sangat sangat signifikan dalam meningkatkan niat berwirausaha masyarakat local Ternate.

Dukungan terhadap temuan ini dapat terlihat dari bagaimana norma social itu berperan dalam masyarakat Ternate. Diantaranya adalah bahwa masyarakat local Ternate cenderung mengkopi berbagai hal yang terjadi atau sedang berkembang disekitarnya. Yakni ada kecenderungan untuk saling meniru satu dengan yang lainnya. Perilaku ini pun Nampak dalam bidang wirausaha masyarakat local. Jika berada berada dengan komunitas yang memiliki usaha maka cenderung juga akan melakukan sebuah usaha. Bahkan usaha yang dilakukan juga cenderung memiliki kesamaan. Oleh sebab itu masyarakat local cenderung akan menggeluti bisnis yang cenderung sama.

Hasil penelitian ini mendukung hasil penelitian terdahulu yang dilakukan oleh (Lieli, 2011) bahwa norma sosial berpengaruh terhadap minat wirausaha. Studi mengenai niat kewirausahaan mahasiswa masih terbuka luas untuk dielaborasi dalam berbagai konteks. Untuk kelompok faktor sosio demografi, isu jenis kelamin, pekerjaan orang tua, bidang studi dan pengalaman kongkrit dalam berwirausaha merupakan faktor-faktor yang diteliti dalam studi ini karena studi-studi yang sudah dilakukan terdahulu belum memperlihatkan arah yang jelas. Faktor jenis kelamin dalam beberapa penelitian memperlihatkan berpengaruh terhadap niat kewirausahaan mahasiswa, yaitu mahasiswa memiliki niat berwirausaha yang lebih tinggi daripada mahasiswi (Rasheed, 2000; Nishanta, 2008). Namun hal yang sama tidak ditemukan dalam studi Johnston et al. (2010). Dalam penelitian ini, tidak ditemukan adanya perbedaan yang signifikan antara niat kewirausahaan mahasiswa dengan mahasiswi. Hal ini dapat menjadi indikasi bahwa calon wirausaha muda terdidik tidak dibatasi oleh jenis kelamin. Data pelengkap yang diperoleh dalam penelitian ini menunjukkan sebagian besar responden mahasiswi telah menjalankan praktek berwirausaha sambil berkuliah dalam bentuk usaha MLM, menjual pulsa elektronik terdapat kesan mahasiswi lebih luwes dalam berwirausaha sambil kuliah ketimbang para mahasiswa. 


\section{Locus of Control berpengaruh terhadap implementasi minat wirausaha}

Hipotesis ketiga menyatakan bahwa Locus of Control berpengaruh terhadap implementsi minat wirausaha tidak terbukti atau ditolak. Artinya Locus of Control yang semakin baik tidak dapat meningkatkan implementasi minat wirausaha bagi masyarakat Kota Ternate. Bila dihubungkan dengan tingkat pendidikan responden yang didominasi dengan jenjang pendidikan SMA atau yang sederajad, dan jenjang pendidikan tersebut belum mampu untuk mengimplementasikan minat untuk berwirausaha, walaupun Locus of Control sudah berjalan dengan sangat baik.

Hasil penelitian ini tidak mendukung hasil penelitian sebelumnya yang dilakukan oleh (Intan, 2015) bahwa ada hubungan positif dan signifikan antara locus of control internal dengan dengan minat berwirausaha. Hubungan positif dari penelitian tersebut menggambarkan bahwa Semakin tinggi locus of control internal maka semakin tinggi minat berwirausaha mahasiswa, dan sebaliknya semakin rendah locus of control internal semakin rendah pula minat berwirausaha mahasiswa. Hal tersebut sesuai dengan pendapat Rauch dan (Rauch. A, 2007) bahwa faktor yang berkaitan dengan keberhasilan kewirausahaan salah satunya adalah locus of control, dan locus of control yang berperan tersebut adalah locus of control internal. Dengan demikian, locus of control internal yang tinggi pada mahasiswa psikologi pada akhirnya juga mempengaruhi minat berwirausaha yang tinggi. Hal tersebut didukung oleh peneltitian yang dilakukan oleh (Parsa, 2011) bahwa locus of control internal menyumbang cukup tinggi terhadap keberhasilan kewirausahaan.

\section{Norma sosial berpengaruh terhadap implementasi minat wirausaha}

Hipotesis keempat yang menyatakan bahwa norma sosial berpengaruh terhadap implementasi minat wirausaha tidak terbukti atau ditolak. Artinya norma sosial yang semakin baik di masyarakat Kota Ternate tidak dapat membuat masyarakat tersebut untuk mengimplementasikan minat berwirausaha. Jika diperhatikan tingkat usia responden yang pada umumnya masih remaja dan pengalaman kerjanyapun masih rendah sehingga belum mampu untuk mengimplementasikan minat berwirausaha.

Hasil penelitian ini memiliki kesamaan dengan hasil penelitian terdahulu yang dilakukan oleh (Noormalita, 2017) bahwa norma sosial tidak berpengaruh terhadap implementasi minat wirausaha. Sarafino (1994) mengatakan bahwa social support adalah kesenangan yang dirasakan, penghargaan akan kepedulian, atau bantuan yang diperoleh individu dari orang lain, dimana orang lain disini dapat diartikan sebagai perorangan atau kelompok. Hal tersebut menunjukkan bahwa segala sesuatu yang ada di lingkungan menjadi dukungan sosial atau tidak, tergantung pada sejauh mana individu merasakan hal tersebut sebagai dukungan sosial. Para mahasiswa atau remaja akhir bukan hanya dukungan sosial yang dapat mempengaruhi tinggi rendahnya need for achievement namun dipengaruhi juga oleh beberapa faktor internal seperti usia, jenis kelamin, kemampuan, minat, harapan atau keyakinan (Toding., et al., 2015). Hal ini sesuai dengan penelitian yang dilakukan oleh (Rolaf, 2006 dalam Toding., et al., 2015) yang menyatakan bahwa konsep diri berhubungan dengan motivasi berprestasi pada remaja, apabila remaja merasa dirinya saat ini kurang berprestasi, namun dirinya merasa mampu untuk berprestasi maka remaja tersebut akan termotivasi sendiri untuk meningkatkan prestasinya.

\section{Minat wirausaha berpengaruh terhadap implementasi minat wirausaha}

Hipotesis kelima yang menyatakan bahwa minat wirausaha berpengaruh terhadap implementasi minat wirausaha terbukti atau diterima. Artinya minat wirausaha yang semakin tinggi di masyarakat Kota Ternate maka dapat meningkatkan implementasi minat wirausaha. Hal 
tersebut dapat didukung oleh persepsi responden tentang minat wirausaha yang pada umumnya dipersepsikan sudah berjalan dengan baik, dan bahkan indikator (Y1.5) menyatakan bahwa responden berharap suatu saat dapat mengelola sebuah bisnis sendiri, dan (Y1.7) menyatakan responden berharap menjadi seorang pengusaha yang sukses dapat dipersepsikan oleh responden sudah sangat baik. Sedangkan indikator yang lain yang dipersepsikan sudah berjalan dengan baik yaitu indikator (Y1.1) menyatakan responden memiliki hasrat yang kuat untuk mnjadi seorang wirausaha, (Y1.2) respond memiliki cita-cita untuk menjadi seorang wirausaha, Y1.3) menyatakan responden memiliki impian untuk menjadi seorang wirausaha, (Y1.4) menyatakan responden berharap untuk dapat memiliki sebuah bisnis, dan (Y1.6) yang menyatakan responden berharap untuk dapat memiliki sebuah perusahaan. Serta tidak ada satupun indikator yang dipersepsikan oleh responden tidak baik.

Hasil penelitian ini mendukung hasil penelitian sebelumnya yang dilakukan oleh (Ni Putu, 2016) bahwa minat wirausaha berpengaruh terhadap implementasi minat wirausaha. Hasil penelitian ini juga sesuai dengan penelitian sebelumnya yang menyatakan sikap berhubungan dengan minat berwirausaha dimana individu yang menunjukkan sikap positif terhadap kewirausahaan, akan lebih mungkin untuk bertindak sebagai seorang pengusaha dan percaya bahwa berwirausaha bukanlah sekedar metode untuk bertahan hidup tetapi cara untuk mencapai aktualisasi diri (Yang, 2013). Semakin baik sikap kewirausahaan maka semakin tinggi minat berwirausaha mahasiswa. Sebaliknya, semakin tidak baik sikap kewirausahaan maka semakin rendah pula minat berwirausaha (Winarsih, 2014).

\section{Lingkungan keluarga sebagai variabel yang memperkuat pengaruh Locus of Control terhadap implementsi minat wirausaha}

Hipotesis yang keenam menyatakan bahwa lingkungan keluarga sebagai variabel yang memperkuat pengaruh Locus of Control terhadap implementsi minat wirausaha tidak terbukti atau ditolak. Artinya lingkungan keluarga yang semakin baik tidak mampu untuk memperkuat pengaruh Locus of Control terhadap implementsi minat wirausaha. Hal tersebut diperkuat dengan persepsi responden terhadap indikator lingkungan keluarga dipersepsikan rata-rata belum baik, serta ada responden yang menyatakan bahwa sangat tidak setuju tentang lingkungan keluarga walaupun persentasinya sangat rendah.

Hasil penelitian ini tidak mendukung hasil penelitian sebelumnya yang dilakukan oleh (Samuel, 2017; Pratiwi dan Wardana, 2016) menunjukkan bahwa dorongan dari lingkungan keluarga mahasiswa dapat meningkatkan minat berwirausaha mahasiswa. Hal ini menunjukkan bahwa semakin tinggi dorongan dari lingkungan keluarga mahasiswa, maka semakin tinggi pula minat berwirausaha mahasiswa. Pernyataan tersebut didukung oleh penelitian (Marini dan Hamidah, 2014) yang menyatakan bahwa lingkungan keluarga memberi pengaruh yang berarti terhadap minat berwirausaha. Apabila keluarga mahasiswa melibatkan peran mahasiswa untuk belajar berwirausaha sejak kecil dengan melatih dan mengasah karakter kewirausahaan, maka minat berwirausaha mahasiswa dapat meningkat. Hal ini didukung oleh (Marini dan Hamidah, 2014) yang mengatakan bahwa anak-anak yang telah memiliki tanggung jawab dalam keluarga yang besar sejak masih kecil dan telah diberi peluang untuk berperan dan terlibat dalam kegiatan kewirausahaan yang ada dalam keluarga akan membekali anak dengan ketrampilan, pola pikir, keyakian dan nilai-nilai yang diperlukan untuk menjadi pengusaha yang sukses, serta memiliki pengaruh pada perkembangan karakteristik psikologis kewirausahaan individu sejak usia dini. 
Emilda Jusmin (2012) hasil penelitian menunjukkan bahwa latar belakang keluarga, kegiatan praktik di unit produksi sekolah dan pelaksanaan pembelajaran kewirausahaan yang tinggi maka kesiapan berwirausaha siswa juga meningkat, dan sebaliknya latar belakang keluarga, kegiatan praktik di unit produksi sekolah dan pelaksanaan pembelajaran kewirausahaan rendah maka kesiapan berwirausaha siswa juga menurun. Hal ini sesuai pendapat-pendapat yang dikemukakan oleh (Solomon, 2001) bahwa keluarga yang berasal wirausaha sangat mendukung anaknya mulai dengan sumber daya dan kemampuan yang memberi manfaat yang baik jika mereka ingin mengejar karir sebagai wirausaha. Hal ini menunjukkan bahwa latar belakang keluarga, kegiatan praktik di unit produksi sekolah dan pelaksanaan pembelajaran kewirausahaan merupakan faktorfaktor yang mempengaruhi kesiapan untuk berwirausaha secara positif. Mery (2010) lingkungan keluarga berpengaruh terhadap minat berwirausaha. Semakin kondusif lingkungan keluarga disekitarnya maka akan semakin mendorong seseorang untuk menjadi seorang wirausaha. Apabila lingkungan keluarga mendukung maka seseorang akan semakin tinggi niatnya untuk menjadi wirausaha dibandingkan jika tidak memiliki dukungan dari lingkungan keluarga.

\section{Lingkungan keluarga sebagai variabel yang memperkuat pengaruh minat wirausaha terhadap implementasi minat wirausaha}

Hipotesis ketujuh menyatakan bahwa lingkungan keluarga sebagai variabel yang memperkuat pengaruh minat wirausaha terhadap implementasi minat wirausaha tidak terbukti atau ditolak. Artinya lingkungan keluarga yang semakin baik tidak mampu untuk memperkuat pengaruh minat wirausaha terhadap implementasi minat wirausaha. Walaupun persepsi responden terhadap indikator implementasi minat wirausaha dipersepsikan sudah berjalan dengan baik dan tidak ada satu indikator yang dipersepsikan tidak baik.

Hasil penelitian ini tidak mendukung hasil penelitian sebelumnya yang dilakukan oleh (Sarwoko, 2011) yang menemukan bahwa mahasiswa yang latar belakang keluarga atau saudaranya memiliki usaha ternyata memiliki tingkat intensi kewirausahaaan yang lebih besar dibandingkan mahasiswa yang keluarga atau saudaranya tidak memiliki usaha. (Rosmiati, 2015) menyatakan bahwa pengalaman orang tua ialah dorongan berupa pendapat terhadap sesuatu hal berdasarkan pengetahuan dan pengalaman yang dimilikinya yang berguna untuk memberikan masukan sehingga akhirnya mempengaruhi keputusan yang akan diambil. Alma (2007) faktor sosial yang berpengaruh terhadap minat berwirausaha ialah masalah tanggung jawab terhadap keluarga. Seringkali terlihat bahwa terdapat pengaruh dariorang tua yang bekerja sendiridan memiliki usaha sendiri yang cenderung anaknya akan menjadi pengusaha pula. Cahyono (2010) mengemukakan bahwa pekerjaan orang tua berpengaruh signifikan terhadap intensi kewirausahaan.

\section{Lingkungan keluarga sebagai variabel yang memperkuat pengaruh norma sosial terhadap implementasi minat wirausaha}

Hipotesis kedelapan yang menyatakan bahwa lingkungan keluarga sebagai variabel yang memperkuat pengaruh norma sosial terhadap implementsi minat wirausaha tidak terbukti atau ditolak. Artinya lingkungan keluarga yang semakin baik tidak mampu untuk memperkuat pengaruh norma sosial terhadap implementsi minat wirausaha. Hasil penelitian ini sama dengan hasil penelitian terdahulu yang dilakukan oleh (Purbo Jadmiko, 2018) tentang pengaruh Dukungan Keluarga Sebagai Pemoderasi Pengaruh antara Dukungan Pendidikan Terhadap Minat Menjadi Wirausaha. Hasil pengujian hipotesis dukungan keluarga memoderasi pengaurh antara dukungan pendidikan terhadap minat menjadi wirausaha menunjukkan tidak terdukung. Hasil penelitian ini 
tidak sejalan dengan penelitian yang dilakukan oleh (Adhitama, 2014) yakni semakin kondusif lingkungan keluarga dan masyarakat disekitarnya maka akan semakin mendorong seseorang untuk menjadi seorang wirausaha. Apabila lingkungan keluarga dan masyarakat mendukung, maka seseorang akan semakin tinggi niatnya untuk menjadi wirausaha dibandingkan jika tidak memiliki dukungan dari lingkungan keluarga dan masyarakat. Niat berwirausaha dipengaruhi oleh 2 faktor yaitu eksternal dan internal. Ketika faktor eksternal seperti adanya dukungan pendidikan mempengaruhi niat berwirausaha seorang mahasiswa, maka faktor internal juga secara langsung akan mendorong hal tersebut. Selanjutnya, tidak terbuktinya hipotesis tentang dukungan keluarga memoderasi pengaruh antara dukungan pendidikan terhadap minat menjadi wirausaha mengindikasikan bahwa responden khususnya mahasiswa meskipun telah mempersepsikan adanya dukungan keluarga untuk menjadi seorang wirausahawan namun belum mampu mempengaruhi minat mereka untuk menjadi wirausahawan. Hasil penelitian ini menyimpulkan bahwa dukungan keluarga tidak memperkuat pengaruh antara dukungan pendidikan terhadap minat menjadi wirausahawan. Hasil tersebut juga mengidikasikan bahwa terdapat faktor-faktor selain dukungan pendidikan yang menjadi faktor dominan mahasiswa memiliki minat menjadi wirasuahawan. Disisi lain, minat wirausaha juga dapat diperoleh dari pengalaman mereka dalam dunia bisnis.

\section{KESIMPULAN DAN SARAN}

\section{Kesimpulan}

Berdasarkan hasil penelitian dan pembahasan dapat ditarik kesimpulan sesuai dengan perumusan masalah sebagai berikut: Locus of Control masyarakat lokal Ternate sangat baik hal ini terlihat dari nilai rata-rata variable yang sudah tinggi tetapi tidak berpengaruh terhadap niat berwirausaha. Hal ini menunjukkan bahwa variable locus of control tidak dapat dijadikan sebagai predictor terhadap minat wirausaha. Temuan ini didukung oleh fakta empiric di lokus riset. Di mana masyarakat local kurang memiliki minat yang baik terhadap bidang wirausaha. Berikutnya Norma social terbukti secara nyata memiliki pengaruh terhadap minat wirausaha masyarakat local Kota Ternate. Arah pengaruhnya bersifat positif artinya bahwa jika norma social semakin baik maka akan menyebabkan semakin baiknya minat wirausaha masyarakat local Kota Ternate. Demikian pula sebaliknya, bila norma sosial yang terjadi di masyarakat tidak kondusif atau tidak baik maka dapat menurunkan minat berwirausaha bagi masyakat Kota Ternate. Selanjutnya, locus of control tidak terbukti memiliki pengaruh terhadap peningkatan implementasi minat berwirausaha masyarakat Kota Ternate. Sehingga walaupun masyarakat local Kota Ternate memiliki tingkat locus of control yang baik tetapi tidak dapat meningkatkan implementasi minat wirausaha. Hasil ini didukung olah bukti empiric bahwa tidak banyak masyarakat local yang menjadi pelaku usaha di Kota Ternate.

1. Norma sosial terbukti tidak memiliki pengaruh terhadap implementasi minat wirausaha masyarakat local Kota Ternate. Meskipun norma social memiliki pengaruh terhadap minat wirausaha tetapi tidak dapat secara langsung terhadap terhadap iplementasi minat wira usaha. Hal ini menegaskan bahwa peran minat menjadi penting dalam penelitian ini.

2. Minat wirausaha berpengaruh terhadap implementasi minat wirausaha di kalangan masyarakat local Kota Ternate. Arah pengaruhnya adalah bersifat positif. Hal ini berarti bahwa jika minat wirausaha itu baik maka akan menyebabkan minat implememtasi minat itu menjadi tinggi. 
Namun demikian, jika minat masyarakat local itu rendah maka akan menyebabkan implementasi minat wirausaha itu akan rendah juga. Sehingga dapat dikatakan bahwa terbatasnya masyarakat local Kota Ternate yang menjadi wirausahawan itu karena pengaruh minat dan norma social masyakat asli yang belum cukup baik.

3. Lingkungan keluarga sebagai variable moderating antara locus of control terhadap implementsi minat wirausaha tidak terbukti atau ditolak. Hal ini menunjukkan bahwa lingkungan keluarga tidak dapat memperkuat atau memperlemah hubungan kedua variable tersebut. Sehingga variable lingkungan keluarga bukan merupakan sebuah predictor.

4. Lingkungan keluarga tidak terbukti sebagai variable yang dapat memoderasi hubungan antara minat wirausaha terhadap implementasi minat wirausaha. Sehingga hal ini menunjukkan bahwa lingkungan keluarga bukan sebagai variabel yang memperkuat pengaruh antara minat wirausaha terhadap implementasi minat wirausaha di Kota Ternate, akan tetapi sebagai variabel yang memperlemah.

5. Lingkungan keluarga sebagai variabel moderasi pengaruh norma sosial terhadap implementasi minat wirausaha tidak terbukti atau ditolak. Hal ini menunjukkan bahwa lingkungan keluarga bukan sebagai predictor.

\section{Saran}

Berdasarkan hasil kesimpulan di atas, maka dapat diambil saran sebagai berikut:

1. Variabel norma sosial yang makin baik dapat meningkatkan minat berwirausaha, namun persepsi responden terhadap semua item-item variabel secara keseluruhan masih berada pada kisaran di bawah 4 maka belum menunjukkan hasil yang baik sekali. Sehingga untuk meningkatkan minat wirausaha perlu dilakukan peningkatan norma social melalui berbagai program-program yang sistematis. Seperti pelatihan, penyuluhan, dan pendidikan di berbagai institusi pendidikan.

2. Oleh karena minat wirausaha memiliki pengaruh yang baik terhadap implementasi wira usaha terhadap implementasi wirausaha maka perlu dilakukan dengan cara meningkatkan peran minat wirausaha ini. Beberapa program yang dilakukan adalah mendorong masyarakat local untuk lebih memahami tentang dunia usaha dengan cara melakukan pembinaan dan pelatihan. Termasuk juga dengan memberikan insentif khusus kepada masyarakat local untuk mendapatkan akses terhadap dunia usaha. Misalnya adanya pemberian insentif di dalam permodalan. Yaitu dengan memberikan bantuan modal usaha dengan bunga yang ringan bagi para pelaku usaha kecil. Termasuk juga dengan memberikan fasilitas dalam mendapatkan lokasi usaha-usaha yang strategis.

\section{Daftar Pustaka}

Adhitama, P.P. (2014). Faktor-faktor yang Mempengaruhi Minat Berwirausaha (Studi Kasus Mahasiswa Fakultas Ekonomika dan Bisnis UNDIP, Semarang). Hasil Penelitian yang tidak dipublikasikan. Fakultas Ekonomi UNDIP, Semarang

Alas, R., Übius, U., Lorents, P., \& Matsak, E. (2017). Corporate Social Responsibility In European And Asian Countries. Jurnal Manajemen Bisnis Dan Inovasi (JMBI) UNSRAT Vol. 4 No. 1 
Alma, B. (2007). Kewirausahaan, Bandung:Alfabeta.

Asimkopoulos, G.; Hernandez, V.; Miguel, J.P. (2019). Entrepreneurial Intention of Engineering Students: The Role of Social Norms and Entrepreneurial Self-Efficacy. Sustainability. Vol. 11/Issue.16.

Ayodele, K.O. (2013). Demographis, Entrepreneurial Self efficacy and Locus of Control as Determinats of Adolescents Entrepreneurial Intention in Ogun State, Nigeria. European Journal of Business and Social Sciences, 1(12): 59-67

Cahyono, A. (2010). Faktor-Faktor Yang Mempengaruhi Intensi Kewirausahaan Mahasiswa Program Manajemen Bisnis Fakultas Ekonomi Universitas Kristen Petra Tahun 20062009, http://dewey.petra.ac.id/jiunkpe_dg_16679

Dinis, A., Arminda, D.P., Fereira, J., Raposo, M., dan Ricardo G.R. (2013). Psychological Characteristics and Entrepreneurial Intentions Among Secondary Students. Journal of Small Business and Enterprise Development, 55 (8/9): 763-780

Emilda J., 2012. Pengaruh Latar Belakang Keluarga, Kegiatan Praktik di Unit Produksi Sekolah, dan Pelaksanaan Pembelajaran Kewirausahaan terhadap Kesiapan Berwirausaha Siswa SMK di KABUPATEN TANAH Bumbu. Jurnal Pendidikan Teknologi dan Kejuruan, Volume 21, Nomor 1.

Fagbohungbe, Oni Bamikole , Jayeoba, Foluso Ilesanmi . 2012. Locus of Control, Gender and Entrepreneurial Ability

Hisrich, R.D., Peters, M.P., and Shepherd, D.A. (2008). Kewirausahaan Edisi 7. Edisi Bahasa Indonesia. Jakarta: Salemba Empat.

Hisrich, R. D., and M. P. Peters. 1998. Entrepreneurship. Boston: Irwin/McGraw-Hill.

I Gusti Lanang Agung Adnyana dan Ni Made Purnami, 2016. Pengaruh Pendidikan Kewirausahaan, Self Efficacy dan Locus of Control pada Niat Berwirausaha). E-Jurnal Manajemen Unud, Vol. 5, No. 2, 2016: 1160-1188. ISSN: 2302-8912

Indarti, N. dan Kristiansen, S. . 2003. Dseterminants Of Enterpreneurial Intention The Case of Norwegian Students. Gadjah Mada International Journal of Business January 2003, Vol. 5, No. 1, pp. 79-95

Intan, N.,V.(2015). Hubungan Antara Locus of Control Internal dengan Minat Berwirausaha. Hasil penelitian yang tidak dipublikasi

Johnston, K.A, Andersen, B.K., Davidge-Pitts, J. \& Ostensen-Saunders, M. 2010. Identifying ICT Entrepreneurship Potential in Students. Paper was presented at the Proceedings of Informing Science \& IT Education Conference (INSITE), Italy, 21-24 Juni

Karamoy, H., \& Tulung, J. E. (2020). The Effect Of Banking Risk On Indonesian Regional Development Bank. Banks and Bank Systems, 15(2), 130-137 
Karamoy, H., \& Tulung, J. E. (2020). The Effect Of Financial Performance And Corporate Governance To Stock Price In Non-Bank Financial Industry. Corporate Ownership \& Control, 17(2), 97-103.

Lieli, S., dan Sirine, Hani (2011). Faktor-Faktor yang Berpengaruh Terhadap Niat Kewirausahaan (Entrepreneurial Intention) (Studi Terhadap Mahasiswa Universitas Kristen Satya Wacana, Salatiga). Jurnal Manajemen dan Kewirausahaan, VOL.13, NO. 2: 124-134

Marini, C. K., dan Hamidah, S., (2014). Pengaruh Self-Efficacy, Lingkungan Keluarga, dan Lingkungan Sekolah Terhadap Minat Berwirausaha Siswa SMK Jasa Boga. Jurnal Pendidikan Vokasi, 4(2), 195-207

Mojambo, G. A., Tulung, J. E., \& Saerang, R. T. (2020). The Influence of Top Management Team (TMT) Characteristics Toward Indonesian Banks Financial Performance During The Digital Era (2014-2018). JMBI UNSRAT (Jurnal Ilmiah Manajemen Bisnis dan Inovasi Universitas Sam Ratulangi)., 7(1).

Ni Putu Pebi Ardiyani \& A.A.G. Agung Artha Kusuma, (2016). Pengaruh Sikap, Pendidikan dan Lingkungan Keluarga terhadap Minat Berwirausaha. E-Jurnal Manajemen Unud, Vol. 5, No.8, 5155-5183. ISSN: 2302-8912

Nishanta, B. (2008). Influence of Personality Traits and Socio-demographic Background of Undergra-duate Students on Motivation for Entrepre-neurial Career: The Case of Srilanka.

Paper was presented at the Euro-Asia Management Studies Association (EAMSA) Conference, Japan

Noormalita, P. (2017). Analisis Faktor-Faktor yang Berpengaruh pada Minat Berwirausaha Mahasiswa. Jurnal Economia, Volume 13, Nomor 1

Parsa, K. (2011). A Model of Critical Psychological Factors Influencing Entrepreneurship Development in Iran Small and Medium-Scale Industries. European Journalof Scientific Research. Vol.51 No.3, 383-395

Pratiwi, Y., dan Wardana, I. M., (2016). Pengaruh Faktor Internal dan Eksternal Terhadap Minat Berwirausaha Mahasiswa Fakultas Ekonomi dan Bisnis Universitas Udayana. E-Jurnal Manajemen Unud, 5(8), 5215-5242

Rasheed, H.S. (2000). Developing Entrepreneurial Potential in Youth: The Effects of Entrepreneurial Education and Venture Creation, (http://USASEB 2001. Proceedings 063, diakses 3 Oktober 2019)

Rauch, A dan Frese, M. (2007). A Meta-Analysis on the Relationship between Business Owners' Personality Traits, Business Creation, and Success. European Journal of Work and Organizational Psychology 
Rosmiati., Teguh Santosa, Junias., Munawar, 2015. Sikap, Motivasi dan Minat Berwirausaha Mahasiswa. Jurnal Manajemen Dan Kewirausahaan, 17(1): h: 21-30

Susanto, S.C. (2017). Pengaruh Lingkungan Keluarga, Pendidikan Kewirausahaan, dan Efikasi Diri terhadap Minat Berwirausaha Mahasiswa. PERFORMA: Jurnal Manajemen dan StartUp Bisnis. Volume 2, Nomor 3, 277 - 286

Sarafino, E.P. (1994). Health Psychology (2.Ed). New York: Willey

Sarwoko, E. (2011). Kajian Empiris Entrepreneur Intention Mahasiswa. Jurnal Ekonomi Bisnis, 16(2): h:314-323.

Solomon, N., \& Boud, D. (2001). Work-based learning. a new higher education?. SRHE and Open University Press Celtic Court 22 Ballmoor Buckingham MK18 IXW.

Sukmaningrum, S., Rahardjo, M. (2017). Faktor yang Mempengaruhi Minat Wirausaha Mahasiswa Menggunakan Theory of Planned Behavior (Studi pada Mahasiswa Pelaku Wirausaha Fakultas Ekonomika dan Bisnis Universitas Diponegoro). Diponegoro Journal of Management . Volume 6, Nomor 3, Tahun 2017, Halaman 1-12 ISSN (Online): 23373792

Uddin, M.R. dan Bose T.K. 2012. Determinants of Entrepreneurial Intention of Business Students in Bangladesh, International Journal of Business and Management, 7(24): 128-137

Toding, W.R.B., David, L., \& Pali, C. (2015). Hubungan Dukungan Sosial Dengan Motivasi Berprestasi Pada Mahasiswa Angkatan 2013 Fakultas Kedokteran Universitas Sam Ratulangi. Jurnal e-Biomedik (eBm), 3(1)

Tulung, J. E. (2010). Global Determinants of Entry Mode Choice. Journal of Indonesian Economy and Business, 25(2), 155-169.

Tulung, J. E. (2010). The Influence of Top Management Team Composition On Company Performance The Case of Indonesian Mining Companies. International Research Journal of Business Studies, 2(3).

William R. Meek, Desirée F. Pacheco , Jeffrey G. York . (2010). The Impact Of Social Norms On Enterpreneurial Action: Evidence From The Environmental Enterpreneurship Context. Journal of Business Venturing.

Wiriani, W., Piatrini, S.Y dan Ardana. (2013). Efek Moderasi Locus of Control pada Hubungan Pelatihan dan Kinerja pada Bank Perkreditan Rakyat di Kabupaten Badung. Jurnal Ilmiah Akuntansi dan Bisnis, 8(2): 99-105

Yang, J. (2013). The Theory of Planned Behavior and Prediction of Entrepreneurial Intention Among Chinese Undergraduates. Scientific Journal Publishers Ltd, 41(3): h: 367-376 